\title{
Feed intake analysis and organ weights of growing west African dwarf goats fed some browse plants and a concentrate supplement diet
}

\author{
Ocheja J 0a, Uguru J.0 ${ }^{\mathrm{b}}$, Audu Mc, Apeh, U.J ${ }^{\mathrm{d}}$, Shittu, B.A ${ }^{\mathrm{e}}$, and Halilu, $\mathrm{A}^{\mathrm{f}}$
}

a Department of Animal Science, Federal University, Kashere, Nigeria

b Department of Animal Science, Ebonyi State University, Abakaliki, Nigeria

c Department of Animal Production, Kogi State University, Anyigba, Nigeria

d Department of Animal Science, Ambrose Alli University, Ekpoma, Nigeria

e Department of Animal Science, University of Ibadan, Nigeria

f Department of Animal Science, University of Calabar, Nigeria ajosiahocheja@yahoo.co.uk 
Available online at www.refaad.com

VMPH 2(2); 2021: 44-48

Research Article

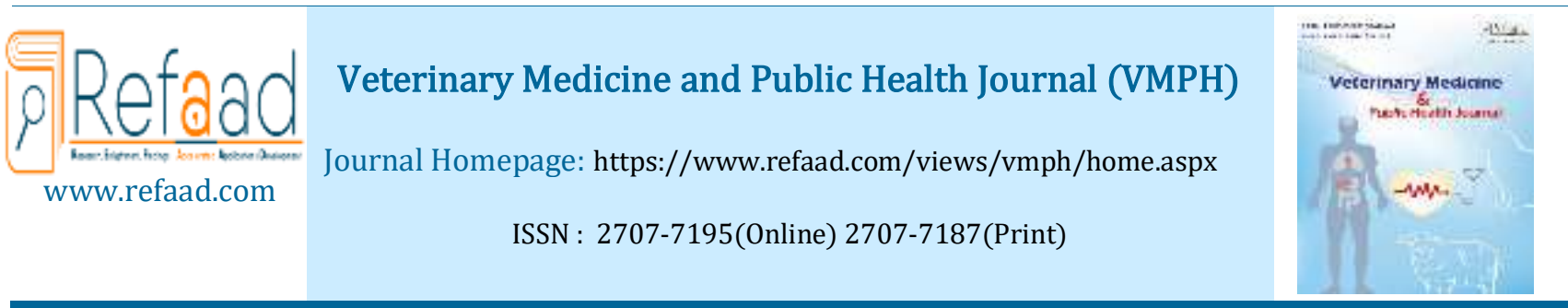

\title{
Feed intake analysis and organ weights of growing west African dwarf goats fed some browse plants and a concentrate supplement diet
}

\author{
Ocheja J O*a, Uguru J.O', Audu Mc, Apeh, U.Jd, Shittu, B.Ae, and Halilu, Af \\ a Department of Animal Science, Federal University, Kashere, Nigeria \\ ${ }^{b}$ Department of Animal Science, Ebonyi State University, Abakaliki, Nigeria \\ c Department of Animal Production, Kogi State University, Anyigba, Nigeria \\ d Department of Animal Science, Ambrose Alli University, Ekpoma, Nigeria \\ e Department of Animal Science, University of Ibadan, Nigeria \\ ${ }^{f}$ Department of Animal Science, University of Calabar, Nigeria
}

* Corresponding author: Ocheja J O. Email: josiahocheja@yahoo.co.uk

How to cite this article: Ocheja J O. et al., Feed intake analysis and organ weights of growing west African dwarf goats fed some browse plants and a concentrate supplement diet. Veterinary Medicine and Public Health Journal 2(2); 2021: 4448.

DOI: https://doi.org/10.31559/vmph2021.2.2.3 Received Date: 15/10/2020 Revised Date: 13/11/2020 Accepted Date: 12/12/2020

\section{Abstract}

The study evaluated the feed intake and organ weights of sixteen growing West African dwarf bucks fed some browse species and a concentrate supplement diet. The goats were allotted into four (4) treatments of four goats each. The goats were fed leaves from Gmelina, (Gmelina aborea)) Tamarind, (Tamarindus, Neem (Azadirachta indica) and Teak leaves (Tectona grandis) at 200g/goat/day for Treatments 1, 2, 3and 4 respectively and a concentrate supplement diet at $100 \mathrm{~g}$ per goat/day for a duration of fifty (50) days. Known volume of water was served, feed and water intake were monitored and recorded The experimental design was a completely randomized design , data were analysed using a one way analysis of variance and least significant difference to separate the significant means using SPSS statistical package for windows 23 , 2015 version .Concentrate and browse samples were analysed using the methods of AOAC (2000), daily browse intake (134.22- 245.44g), total daily feed intake(225.53 - 339.87g), daily water intake(340.00$420.00 \mathrm{ml})$ and daily supplement intake values were all significantly ( $p>0.05)$ different across the treatment means. The water intake followed similar trend as the dry matter intake. All the organ weights were not significant $(\mathrm{P}<0.05)$, the weights were within normal ranges for goats. It was therefore concluded that Gmelina arborea was the most preferred by the goats in terms of intake, it also had the best array of nutrients. The four browse species were safe for the goats and were therefore recommended for goat feeding especially during the long dry season. Further research using other breeds and classes of goats as well as other species of ruminants such as sheep and cattle was also recommended.

Keywords: Browse; Fed intake; Organ Weights; Concentrate; West African Dwarf Goats. 


\section{Introduction}

Good nutrition is a prerequisite for good health, good reproduction, high milk yield, fast growth rate and a successful goat production system (Peacock, 1996). The goat is considered superior to other ruminants in its utilization of poor quality and high fibre forage for its body maintenance and production (Howe et.al., 1988). An enhancement of this potential through improved utilization of supplements and agricultural wastes could enhance the productivity of these animals. Norton, (1994) reported that the nutritive value of a feed is measured by its ability to deliver nutrients to the animal for maintenance and growth in absence of toxic factors.

Steele (1996) reported the daily dry matter intake of goats in the tropics to be $4-5 \%$ of body weight for dairy breeds, $3 \%$ of body weight for meat goats and up to $8 \%$ for temperate dairy goats.

Inadequate grasses during the long dry season necessitates the utilization of browse species to feed ruminants, especially during the long dry season, and also supplementation with concentrate (Okolo et. al.,2012; Okpanachi et.al.,2016; Mafindi et.al.,.,2018)

Toxic substances in feeds will reflect in the liver and kidneys by enlargement (Ngi, 2012), Ocheja et al in an earlier study underscored the importance of organ weight determination in animals. This makes organ weight determination imperative since it is a veritable way of testing for the safety or otherwise of feed materials.

From the forgoing it is important to carry out feed intake and organ weights analysis considering the fact that many by -products are now used to feed ruminant animals due to inadequate grasses and legumes during the long dry season, with a view to determining the nutritive value and safety of feed materials fed to ruminant animals

The aim of this work therefore was to assess the feed and water intake as well as organ weights of growing West African dwarf goats fed, some browse species supplemented with a concentrate diet.

\section{Materials and Methods}

\section{Experimental Location:}

The experiment was conducted at the Sheep and Goat unit of Livestock Teaching and Research farm, Kogi State University, Anyigba. Anyigba is located in the derived Guinea Savannah zone of Nigeria on latitude $7^{0} 15^{\prime}$ and $7^{0} 29^{\prime} \mathrm{N}$ of the equator and longitudes 7011' and 7032'E of the Greenwich meridian. The zone lies in the warm humid climate of the tropics with distinct wet and dry seasons in April to October and November to March respectively with annual rainfall ranging from 1400 $1500 \mathrm{~mm}$ and an ambient temperature of about $25^{\circ} \mathrm{C}$ with the highest in March and April the average altitude is 420 meters above sea level (Ifatimehin and Ufuah 2006).

Feed preparation, Experimental Animals, and Management:

Sixteen growing West African dwarf bucks were used for the study the animals were housed individually and treated with Ivomec, for endo and ecto parasite control at $0.3 \mathrm{ml}$ each and oxytetracycline, hydrochloric and procaine penicillin at $2.0 \mathrm{ml}$ each as prophylactic treatment to provide a good and common health status. The browse species used for this experiment were obtained from within Kogi State University campus, Anyigba. and wilted for 24 hours to reduce the moisture content before feeding the concentrate components were cashew nut shell, Maize offal (MO), Bambara nut offal (BO), Fish offal (FO), Rice offal (RO), Wood ash (WA), Bone meal and Table salt These ingredients were ground to desired texture. The goats were allotted in a Completely Randomized Design (CRD) into four (4) treatments. Each treatment had four (4) goats. Each goat was fed $100 \mathrm{~g}$ of the supplement diet per day.

The leaves, Gmelina, (Gmelina aborea) Tamarind, (Tamarindus indicus), Neem (Azadirachta indica) and Teak (Tectona grandis) were wilted for 24 hours and fed at $200 \mathrm{~g}$ /goat/day for each treatment, the concentrate was fed 1 hour later

Feed served the goats was weighed daily and the left over was also weighed and subtracted from the quantity of feed served to determine the feed intake. Known volume of water was served and the water intake of the goats recorded. The study duration was fifty (50) days, after a preliminary $\begin{array}{lllll}\text { feeding } & \text { period } & \text { of } & 7 & \text { days. }\end{array}$ 
Table (1): Composition of Experimental Diets (\%) Dry matter

\begin{tabular}{cc}
\hline Feed Ingredients & Composition \\
Cashew nut shell (CNS) & 10.00 \\
Maize offal (MO) & 27.00 \\
Bambara nut offal (BO) & 48.00 \\
Fish offal (FO) & 5.50 \\
Rice offal (RO) & 5.00 \\
Wood ash (WA) & 1.00 \\
Bone meal & 2.00 \\
Table salt & 1.50 \\
\hline Total & 100 \\
\hline Nutrient & \\
Crude protein & Composition \\
Crude fibre & 18.47 \\
Gross energy (Kcal/kg diet) & 14.16 \\
\hline
\end{tabular}

\section{Organ Weights Determination:}

On the last day of the experiment two goats were slaughtered from each treatment the heart, liver, kidney, lungs and spleen were cut off and removed after opening the carcass of the goats, they were weighed and their weights converted to percentage of slaughter weight

\section{Proximate Chemical Analysis:}

Samples of the browse leaves and the supplement diet were analyzed for their proximate composition using standard procedure according AOAC (2000)

\section{Experimental design and Statistical Analysis:}

The experimental design was a completely randomized design (CRD). Data were analysed using a one-way analysis of variance (ANOVA) and significant differences were separated using least significant difference (LSD) with the aid of SPSS version 23, 2015 edition.

\section{Results and Discussion}

\section{Proximate Composition of Browse leaves and} Concentrate Diet:

The proximate composition of the browse and concentrate diet is summarized in Table 2.

The protein content of the browse and concentrate diet fell within the values of $12-18 \%$ recommend for growing ruminants in the tropics (NRC, 1996), and also above the critical value of $8 \%$ required to provide adequate ammonia for normal rumen functions (Lakpini, 2002). The fibre and energy of the supplement were within recommended values (Lakpini et. al 2002). The energy value for some of the browses were below recommended values for goats, but compensated for from the supplement.

Table (2): Proximate Composition of browse and supplement (Actual basis) (\%DM)

\begin{tabular}{lccccc}
\hline Nutrients & \multicolumn{3}{c}{ Treatment } & \multicolumn{2}{c}{ SUPP } \\
\hline & $\mathrm{T}_{1}$ & $\mathrm{~T}_{2}$ & $\mathrm{~T}_{3}$ & $\mathrm{~T}_{4}$ & \\
Crude Protein & 9.98 & 11.55 & 8.68 & 9.64 & 17.23 \\
Crude Fibre & 10.20 & 11.50 & 12.66 & 10.88 & 15.50 \\
Nitrogen Free Extracts & 30.12 & 32.06 & 34.01 & 32.23 & 51.85 \\
Ether Extracts & 2.10 & 1.89 & 2.05 & 2.35 & 7.50 \\
Ash & 6.10 & 5.80 & 6.60 & 5.25 & 3.40 \\
Moisture & 4.50 & 37.20 & 36.00 & 39.65 & 4.52 \\
\hline
\end{tabular}

\section{Feed Intake and Water Intake of Experimental Animals:}

The feed and water intake records of the experimental goats is presented in Table 3.

Values for daily browse intake (75.33 $94.43 \mathrm{~g})$, total daily feed intake (225.53 - 339.87g), and water intake $(335.90-420.00 \mathrm{~g})$ were significantly $(\mathrm{p}<0.05)$ different. The daily supplement intake was however not significant $(P>0.05)$. the water intake values appear to be influenced by the feed intake, this was in line with the report of Norton (1994) that water intake in animals is largely determined by the feed (dry matter) intake, this may also mean that none of the 
browse contained any substance that increased water intake.

The daily supplement intake, and total daily feed intake were higher than 44.65 - 91.54g and 216.75 - 258.99g reported by Ocheja et al., (2016) and $130.74-210.37 \mathrm{~g}$ total daily feed intake reported by Arigbede et. al., (2012). who fed cassava leaf- based diets to West African dwarf goats, these discrepancies could be due to the type of concentrates and browse fed to the goats?

Table (3): Feed Intake Records

\begin{tabular}{|c|c|c|c|c|c|}
\hline \multirow{2}{*}{ Parameters } & \multicolumn{3}{|c|}{ Treatments } & & \multirow{2}{*}{ SEM } \\
\hline & $\mathrm{T}_{1}$ & $\mathrm{~T}_{3}$ & $\mathrm{~T}_{4}$ & & \\
\hline Daily Supplement Intake (g) & $94.43^{\mathrm{a}}$ & $91.30^{\mathrm{a}}$ & $75.33^{b}$ & $82.40^{\mathrm{b}}$ & 3.66 \\
\hline Daily Browse Intake (g) & $245.44^{\mathrm{a}}$ & $134.22^{\mathrm{c}}$ & $180.44^{\mathrm{b}}$ & $175.24^{b}$ & 17.98 \\
\hline Total Daily Feed Intake (g) & $339.87 \mathrm{a}$ & $225.53^{b}$ & $255.76^{b}$ & $257.63^{b}$ & 18.56 \\
\hline Water intake $(\mathrm{ml})$ & $420.00^{\mathrm{a}}$ & $335.90^{\mathrm{b}}$ & $336.50^{\mathrm{b}}$ & $340.00^{\mathrm{b}}$ & 20.80 \\
\hline
\end{tabular}

$\mathrm{a}, \mathrm{b}, \mathrm{c}$ Treatment means on the same row with different superscripts differ significantly $(\mathrm{p}<0.05)$

SEM Standard Error of Means

\section{Organ Weights of the Experimental Goats:}

All the organ weights determined were not significantly $(\mathrm{P}<0.05)$ different, all the recorded organ weights were within normal weights for goats, this was an indication that the browse and concentrate diet were safe for the goats, this result corroborates that obtained by Ocheja et. al., (2016), when they fed supplement diets containing graded levels of cashew nut shell to growing West African dwarf goats, and that of Okpanachi et.al., (2016), for West African dwarf goats fed graded levels of cashew pulp meal-based diets. Internal organs like the heart, and liver will enlarge if the diets contain substances that are injurious, the normal weight for the heart showed that the kidney was not overburdened, the kidney is an excretory organ, the excretory organs of the goats were not impaired (Ngi, 2012). However, Ozung and Anya (2018), reported significant $(\mathrm{P}<0.05)$ values in the weights of the organs when they fed West African dwarf goats with cassava peels meal-based diets with African yam bean concentrate. Odoemedem et. al., (2014), also obtained significant $(\mathrm{P}<0.05)$ differences in the weights of the internal organs in West African dwarf bucks fed Panicum maximum supplemented concentrate containing bambara nut meal. The observed differences could be attributed to differences in the concentrates and forages fed to the goats.

Table (4): Organ Weights (\% of Slaughter Weight) of Growing West African Dwarf Goats Fed some browse species and a supplement Diet

\begin{tabular}{|c|c|c|c|c|c|}
\hline \multirow[t]{2}{*}{ Organs } & \multicolumn{3}{|c|}{ Treatments } & & \multirow[t]{2}{*}{ SEM } \\
\hline & $\mathrm{T}_{1}$ & $T_{2}$ & $\mathrm{~T}_{3}$ & $\mathrm{~T}_{4}$ & \\
\hline Liver & 1.66 & 1.61 & 1.59 & 1.64 & 0.10 \\
\hline Spleen & 0.16 & 0.15 & 0.14 & 0.15 & 0.05 \\
\hline Heart & 0.61 & 0.57 & 0.53 & 0.56 & 0.0 \\
\hline Lungs & 1.34 & 1.31 & 1.32 & 1.29 & 0.11 \\
\hline Kidney & 0.63 & 0.57 & 0.62 & 0.60 & 0.03 \\
\hline
\end{tabular}

$\mathrm{SEM}=$ Standard Error of the Means.

\section{Conclusion and Recommendations}

\section{Conclusion:}

All the organ weights tested fell within normal values for goats.

The four browse plants fed to the goats, had no adverse effects on the feed intake and organ weights of the Goats.

Recommendations: The four browse plants tested may be recommended for feeding goats especially during the long dry season. Further research should be carried out using other species of ruminants such as sheep and cattle. 


\section{References}

1. AOAC (2000). Association of Official Analytical Chemists. Official methods of Analysis $17^{\text {th }}$ edition Washington, D.C. Pp. 3 - 22.

2. Arigbede, A.O., Adedeji, O.Y., Falola, O. O. and Saka, A.A. (2012). Performance characteristics and nutrient intake of West African Dwarf Goats fed cassava leaf hay- based diets. Proceeding 17th Annual Conference of Animal Science Association of Nigeria, Abuja $9^{\text {th }}-13^{\text {th }}$ September, 2012Pp. 559-562.

3. Ifatimehin, O. O, \& Ufuah M. E (2006). The effect of a spatial Structure on Rural Economy; A Case of Kogi State University on Anyigba and its Environs Confluence, Journal of Environmental Studies 1(2): 61-70

4. Lakpini, C. A. M. (2002). Feeds and feeding strategy for small ruminants in various physiological states in: Lakpini CAM, Adamu A.M Ehoche O.W and Gefu O.J. (Editors) Manual for training workshop on small ruminant production held at NAPRI, Zaria, Nigeria $13^{\text {th }}-18^{\text {th }}$ Jan. 2002 Pp. 40-48.

5. Lakpini, C. A. M., Adamu, A. M., Ehoche, O. W. \& Gefu, J. O. (2002). Manual for Small Ruminant Production in Nigeria. Compilation for a Training Workshop on Small Ruminant production held at the National Animal Production Research Institute, Zaria Nigeria $13^{\text {th }}-18^{\text {th }}$ January 2002 Pp. $55-62$.

6. Mafindi U.M, Kiben A.U Zaklag D.U \& Buda I.G (2018) Growth performance of red Sokoto goats fed cowpea husk supplemented with graded levels of Moringa oleifera leaves. Nigerian Journal of Animal Science. 20(2): 173-182.

7. Ngi, J. (2012). The nutritional potentials of sweet orange (Citrus sinensis) fruit peel meal for goat feeding. A Ph. D Thesis Submitted to the Department of Animal Production, University of Agriculture, Makurdi ,Nigeria, 175pp.

8. Norton, B.W. (1994). The nutritive value of tree legume in: Gutteridge $R . G$, and Sheldon $H . M$ (Editors). Forage legumes in Tropical Agriculture, CAB International Walhyford U.K Pp. 177-191.

9. NRC, National Research Council, (1996). Nutrient requirements of beef cattle $7^{\text {th }}$ Rev. Ed. National Academy Press Washington, DC. P. 27.

10. Ocheja J. O, Ayoade J. A, Attah,S, Okwori A.I, .Ocheni j \& Oyibo ,A (2016). Blood Parameters and Qrgan Weights of growing west African Dwarf Goats fed Diets containing graded levels of steam-treated cashew nut shell. 3(4):17 - 22

11. Odoemedem, V.U., Ahamefule, F.O., Aluwe E.U., Ekwe, C.O \& Obi J.I (2014). Carcass Yield and Organ Characteristics of West African Dwarf Bucks fed panicum maximum, supplemented concentrate, containing bambara nut meal. Nigerian Journal of Agric, Food and Environment, 10 (4): 18-24

12. Okolo, F. A., Ocheja J. O, Lalabe B. C. \& Ejiga, P. A. (2012). Digestibility, performance and bioeconomics of growing West African Dwarf Goats fed diets containing graded levels of cashew nut shell. International Journal of Agriculture and Rural Development, (IJARD), 15:1000-1007.
13. Okpanachi, U, Ayoade, J. A, \& Tuleun, C.D. (2016). Carcass Characteristics, Internal Organs and Economics of Feeding Sun Dried Yellow Cashew Pulp Based Diets to West African Dwarf Goats. Animal and Veterinary Sciences. 4(3):1 - 6.

14. Okpanachi, U, Okpanachi GAC Kaye-J, Agu C.I and Odah E.O(2018). Haematological profile and serum biochemistry of West African Dwarf goats fed sundried yellow cashew pulp-based diets. Journal of applied science, 19(4):319-324, https://doi.org/10.3923/jas.2019.319.324.

15. Ozung. P.O. \& Anya M.I. (2018). Performance and Carcass Characteristics of West African Dwarf Goats, Fed Cassava Peel Meal based diets Supplemented with African yam bean concentrate. Journal of Advances in Agric. Science and Technology, 5 (7): 95-108.

16. Steele, M. (1996). Goats. The Tropical Agricultural Series. CTA/Macmillan Pp. 110 - 114. 